\section{More on the fructosamine assay}

\section{Dear Sir,}

The recent paper of Flückiger et al. [1] on evaluation of fructosamine test is remarkable for its report of enormous intraindividual variations of total serum protein concentration and fructosamine value in Type 1 (insulin-dependent) diabetic individuals. Hölzel [2] found a total (biological plus analytical) intraindividual variation in serum protein of $4.6 \%$ in Type 1 diabetic females (males $3.8 \%$ ), whereas the variations reported by Flückiger are up to six- (and possibly eight-) fold this magnitude. Moreover, we have observed an intraindividual variation of fructosamine concentration of $3.7 \%$ within a single day in Type 1 diabetic patients [3], which is in keeping with Hölzel's estimate of protein variation.

To reconcile the data of Flückiger et al. with those of Hölzel and ourselves, we are forced to postulate an additional source of variation in Flückiger's information. One possible source is specimen collection and handling, with varying degrees of contamination introduced by residual fluid from the indwelling catheters, and incomplete mixing of frozen specimens. We, and no doubt your readership, would be interested to learn how Flückiger et al. were able to exclude such errors as sources of variation.

Yours sincerely,

R. N.Johnson and J. Baker

\section{References}

1. Flückiger R, Woodli T, Berger W (1987) Evaluation of the fructosamine test for the measurement of plasma protein glycation. Diabetologia 30: 648-652

2. Hölzel WGE (1987) Intra-individual variation of some analytes in serum of patients with insulin-dependent diabetes mellitus. Clin Chem 33: 57-61

3. Baker J, Reid I, Holdaway I (1985) Serum fructosamine in patients with diabetes mellitus. NZ Med J 98: 532-535

Dr. R. N.Johnson

Department of Clinical Biochemistry

Green Lane Hospital

Private Bag, Symonds Street

Auckland

New Zealand

\section{Combined response from the authors}

Dear Sir,

Johnson and Baker consider the variation of fructosamine and protein concentrations measured in our evaluation of the fructosamine assay enormous in comparison to that seen in their hands. They suggest problems in specimen collection and handling as explanation for the discrepancy. Drexel et al. are under the impression that under strictly standardised conditions intraindividual variability does not exceed analytical variability. We are going to demonstrate that variability associated with performance of the fructosamine test is comparable in all laboratories.

The coefficient of variation of $3.7 \%$ cited by Johnson and Baker [1] is the median of median values ranging from $2.1-6.8 \%(n=14)$. In Type 2 (non-insulin-dependent) diabetic patients $(n=14)$ the upper range even reached $8.2 \%$. Considering the magnitude of these ranges our coefficients of variation (SD/mean $\times$ FE100) of 9.4 and $12.7 \%$ are roughly comparable. By inference, fluctuations of protein concentrations similar to those seen in our study must have been encountered by Johnson \& Baker. Such ranges are not in conflict with intraindividual variability reported by Hölzel [2]. In the latter investigation variability of analyses in blood drawn in the postbreakfast state once a week over 8 weeks are reported and not on samples drawn at different times during the same day.

Drexel et al., in their study of nondiabetic pregnant women, show that under the strictly controlled conditions of a glucose tolerance test fructosamine values deviate from the mean value by \pm $0-13 \%$. This value by far exceeds analytical variability which in our hands was $2-3 \%$. At an average fructosamine concentration of $1.68 \mathrm{mmol} / 1$ their range of values is $0-0.44 \mathrm{mmol} / 1$, identical to our range for this subgroup.

Furthermore, in a recently published study serum fructosamine determinations were performed in control subjects on postbreakfast blood specimen obtained at regular intervals over 5 weeks. Ranges from 0.15 to $0.9 \mathrm{mmol} / 1$ were observed [3]. This range of values in comparable to that reported by us within a single day.

The uncertainty of a fructosamine determination of up to $1 \mathrm{mmol} / \mathrm{l}$ is therefore well documented in both diabetic and control subjects. In view of the skewed distribution of variability towards lower values $[1,3]$, the uncertainty of a fructosamine determination is probably closer to $0.5 \mathrm{mmol} / 1$ which can lead to misjudgment of the averaged blood glucose concentration by $4 \mathrm{mmol} / 1$. Such uncertainty arising in part from variations in protein concentration and probably also from non-specificity of the test [4] can somewhat be reduced by correction for the protein concentration.

Yours sincerely,

R. Flückiger, T. Woodtli and W. Berger.

\section{References}

1. Baker J, Reid I, Holdaway I (1985) Serum fructosamine in patients with diabetes mellitus. NZ Med J 98: 532-535

2. Hölzel WGE (1987) Intra-individual variation of some analytes in serum of patients with insulin-dependent diabetes mellitus. Clin Chem 33: 57-61

3. Howey JEA, Browning MCK, Fraser CG (1987) Assay of serum fructosamine that minimizes standardization and matrix problems: use to assess components of biological variation. Clin Chem 33: $269-272$

4. Schleicher ED, Wagner E, Gerbitz KD (1987) Evaluation of the fructosamine assay for determination of glycated serum proteins. Diabetologia 30: 578A

Dr. R. Flückiger

Zentrum für Lehre und Forschung Diabetologie

Hebelstraße 20

CH-4031 Basel

Switzerland

\title{
Announcement
}

International Workshop on Implantable Glucose Sensors (under the auspices of the International Society of Artificial Organs)

This workshop will be held from September 27-30, 1988 in GöhrenLebbin, German Democratic Republic. Because of limited access ac- tive participants will be prefered. Deadline for applications: April 1; for abstracts: July 20,1988. For further information please contact: Professor Uwe Fischer, Central Institute of Diabetes "Gerhardt Katsch”, DDR-2201 Karlsburg, German Democratic Republic. 